\title{
PERSEPSI, SIKAP DAN PARTISIPASI MASYARAKAT TERHADAP KONVERSI MINYAK TANAH KE GAS LPG \\ (Studi di Kelurahan Taratara, Kecamatan Tomohon Barat, Tomohon).
}

\author{
Stevianus X. Mentang, \\ stevimentang@unima.ac.id
}

\begin{abstract}
The availability of depleted oil reserves has made world oil prices soar. Consequently, the fuel subsidy swells. Facing this situation, the Government made a policy of converting kerosene to LPG gas.

The methodology used in this study is descriptive qualitative method with data collection techniques through interviews and observations in the community by purposive sampling. Data were analyzed using reduction, display and verification techniques.

The results of the study show: 1) The public perception regarding the conversion of kerosene to LPG gas is quite good. 2) The attitude of the community towards the conversion of kerosene to $L P G$ gas is predominantly in the good category. 3) Community participation in the conversion of kerosene to LPG gas has a dominant distribution in the high enough category.
\end{abstract}

Keywords: perception, attitude, participation, conversion.

\section{Pendahuluan}

Manusia mempunyai banyak kebutuhan yang harus dipenuhi selama hidupnya. Manusia melakukan berbagai macam cara untuk memuaskan kedahagaan akan kebutuhan yang seakan tak terbatas itu. Sayangnya ada fakta bahwa ketidak terbatasan kebutuhan manusia, selalu dibatasi oleh terbatasnya sumber daya yang ada.

Dewasa ini, aktifitas manusia sangat tinggi, sehingga membutuhkan banyak bahan bakar untuk bergerak. Penggunaan BBM terus menerus dan massif, mengakibatkan semakin menipisnya sumber daya energi minyak ini. Krisis energi ini dialami oleh hampir semua negara, termasuk Indonesia.

Ketergantungan Indonesia akan minyak dari Negara-negara Timur Tengah sangatlah besar. Hal ini disebabkan oleh produksi dalam negeri yang tidak mencukupi kebutuhan karena tidak sebanding dengan konsumsi BBM masyarakat. Faktor yang menyebabkan tidak maksimalnya pengelolahan minyak, karena keterbatasan teknologi, modal dan sumber daya manusia.

Kondisi ini membawa konsekuensi, berupa membengkaknya subsidi BBM yakni solar, premium dan minyak tanah sehingga menguras APBN. Untuk menghadapi situasi ini, Pemerintah bersama DPR membuat kebijakan untuk menghapuskan subsidi BBM secara bertahap.

Pengurangan subsidi bahan bakar minyak oleh Pemerintah secara bertahap merupakan pelaksanaan prioritas pembangunan dalam Undang-Undang Nomor 25 Tahun 2000 tentang Program Pembangunan Nasional (Propenas) Tahun 2000-2004, yaitu "Mempercepat Pemulihan Ekonomi dan Memperkuat Landasan Pembangunan" yang dituangkan dalam "Program Peningkatan Efektivitas Pengelolaan Keuangan Negara" yaitu "Peningkatan Efektivitas Pengeluaran Negara". "Menyehatkan Anggaran Pendapatan dan Belanja Negara dengan mengurangi defisit anggaran melalui peningkatan disiplin anggaran pengurangan subsidi dan pinjaman luar negeri secara bertahap, peningkatan penerimaan pajak progresif yang adil dan jujur, serta penghematan pengeluaran".

Hal ini dilakukan karena subsidi yang diberikan untuk bahan bakar minyak setiap tahun sangat besar sehingga pemerintah harus mengeluarkan dana APBN lebih besar lagi seiring meningkatnya harga minyak dunia.

Demi penghematan APBN, mengurangi subsidi BBM adalah satu-satunya jalan yang harus diambil. Setelah melakukan pembatasan subsidi terhadap solar dan premium, selanjutnya dilakukan pencabutan subsidi minyak tanah. Subsidi terbesar adalah minyak tanah karena terbesar penggunanya adalah masyarakat, rumah tangga serta usaha mikro dan industri. Dengan demikian Pemerintah berhemat sekian trilyunan rupiah setiap tahun.

Kebijakan yang dikeluarkan untuk mencabut subsidi adalah dengan mengkonversi 
minyak tanah ke gas LPG. Masyarakat diminta untuk mengganti minyak tanah dengan menggunkan gas LPG. Pengalihan subsidi dan penggunaan minyak tanah ke gas dilakukan melalui pembagian paket LPG $3 \mathrm{Kg}$ tabung beserta isinya, kompor, regulator dan selang secara gratis kepada masyarakat.

Program konversi minyak tanah ke gas LPG ini menurut pemerintah mengandung beberapa pertimbangan, baik pertimbangan secara teknis maupun secara ekonomis. Intinya adalah penggunaan LPG akan jauh lebih efektif dan efisien dibandingkan dengan minyak tanah. Program konversi ini dilaksanakan dengan melibatkan pihak P.T. Pertamina sebagai penyedia dan pendistribusi paket LPG. Program konversi ini ditujukan bagi keluarga miskin atau kurang mampu.

Kota Tomohon Provinsi Sulawesi Utara adalah yang pertama kali menjalankan program ini. Tomohon dijadikan sebagai pilot project program konversi minyak tanah ke gas LPG $3 \mathrm{Kg}$.

Pemerintah Kota Tomohon telah mendata dan menyalurkan paket gas LPG ini di setiap Kelurahan yang tersebar di lima Kecamatan. Salah satunya adalah Kecamatan Tomohon Barat. Dari semua Kelurahan yang ada di Kecamatan Tomohon Barat diantaranya adalah Kelurahan Tara-Tara.

Program konversi ini dipandang sebagai jalan terbaik untuk menjaga kestabilan ekonomi Negara. Akan tetapi sayang dalam pelaksanaannya ternyata benar-benar tidak semudah dengan apa yang diharapkan. Program yang sudah di rencanakan ternyata tidak serta-merta direspon dengan baik oleh masyarakat termasuk masyarakat yang ada di Kelurahan Tara -Tara, Kecamatan Tomohon Barat ini. Konversi minyak tanah ke gas LPG ini, menemui banyak hambatan yakni mengalami penolakan dari masyarakat. Sebagian besar masyarakat menolak digantinya minyak tanah dengan bahan bakar gas LPG.

Berdasarkan latar belakang permasalahan di atas, maka penulis tertarik untuk meneliti tentang "persepsi, sikap dan partisipasi masyarakat terhadap konversi minyak tanah ke gas LPG di Kelurahan Tara-tara, Kecamatan Tomohon Barat, Tomohon".

\section{Rumusan Masalah}

Berdasarkan latar belakang masalah yang diuraikan sebelumnya, maka rumusan masalah dalam penelitian ini adalah:

1. Bagaimana persepsi masyarakat mengenai konversi minyak tanah ke gas LPG.

2. Bagaimana sikap masyarakat terhadap program konversi minyak tanah ke gas LPG

3. Bagaimana partisipasi masyarakat terhadap konversi minyak tanah ke gas LPG

\section{Tujuan Penelitian}

Tujuan yang ingin dicapai dalam penelitian ini adalah:

1. Mendeskripsikan persepsi masyarakat mengenai konversi minyak tanah ke gas LPG.

2. Mendeskripsikan sikap masyarakat terhadap program konversi minyak tanah ke gas LPG

3. Mendeskripsikan partisipasi masyarakat terhadap konversi minyak tanah ke gas LPG

\section{Tinjauan Pustaka}

\section{A. Konsep Persepsi}

Persepsi menurut Morgan, King dan Robinson adalah suatu proses diterimanya suatu rangsangan (obyek, kualitas, hubungan antar gejala maupun peristiwa) dengan cara melihat dan mendengar dunia disekitar kita. Dengan kata lain persepsi dapat juga didefinisikan sebagai segala sesuatu yang dialami manusia (Morgan, King dan Robinson dalam Adi, 2000:105).

Jadi yang dimaksud dengan persepsi adalah suatu proses yang dimulai dari penglihatan dan pendengaran hingga terbentuk tanggapan yang terjadi pada diri individu sehingga individu sadar akan segala sesuatu dalam lingkungannya melalui indera-indera yang dimilikinya (Mahmud, 1990:55).

\section{B. Konsep Sikap}

Thurstone mendefinisikan sikap sebagai derajat efek positif atau efek negatif terhadap suatu objek psikologis (dalam Azwar, 2007). Sikap atau attitude senantiasa diarahkan pada suatu hal, suatu objek. Tidak ada sikap tanpa adanya objek (Gerungan, 2004).

Azwar (2007) menyimpulkan bahwa faktor-faktor yang mempengaruhi pembentukan sikap adalah pengalaman pribadi, kebudayaan, orang lain yang dianggap 
penting, media massa, institusi atau lembaga pendidikan dan lembaga agama, serta faktor emosi dalam diri individu.

a. Pengalaman pribadi

Middlebrook (dalam Azwar, 2007) mengatakan bahwa tidak adanya pengalaman yang dimiliki oleh seseorang dengan suatu objek psikologis, cenderung akan membentuk sikap negatif terhadap objek tersebut.

b. Pengaruh orang lain yang dianggap penting Pada umumnya, individu cenderung untuk memiliki sikap yang konformis atau searah dengan sikap orang yang dianggapnya penting.

c. Pengaruh Kebudayaan

Burrhus Frederic Skinner, seperti yang dikutip Azwar sangat menekankan pengaruh lingkungan (termasuk kebudayaan) dalam membentuk pribadi seseorang.

d. Media Massa

Berbagai bentuk media massa seperti televisi, radio, surat kabar, majalah dan lain-lain mempunyai pengaruh yang besar dalam pembentukan opini dan kepercayaan individu.

e. Lembaga Pendidikan dan Lembaga Agama

Lembaga pendidikan serta lembaga agama sebagai sesuatu sistem mempunyai pengaruh dalam pembentukan sikap dikarenakan keduanya meletakkan dasar pengertian dan konsep moral dalam diri individu.

f. Faktor Emosional

Suatu bentuk sikap terkadang didasari oleh emosi, yang berfungsi sebagai semacam penyaluran frustrasi atau pengalihan bentuk mekanisme pertahanan ego.

\section{Konsep Partisipasi}

Partisipasi atau keikutsertaan para pelaku dalam masyarakat untuk terlibat dalam proses pembangunan ini akan membawa manfaat dan menciptakan pertumbuhan ekonomi di daerah (Suprapto, 2007:8).

Nelson (1979: 163-167 ) menyebut dua macam partisipasi pertama, partisipasi horisontal yaitu partisipasi antara sesama warga atau anggota suatu perkumpulan. Kedua, partisipasi vertikal yaitu partisispasi yang dilakukan oleh bawahan dengan atasan, antar klien dengan patron, atau antara masyarakat sebagai suatu keseluruhan dengan pemerintah.
Partisipasi ditinjau dari fungsi yang diambil oleh masyarakat (pelaku) untuk suatu program, fungsi yang dapat diambil oleh masyarakat dalam berpartisipasi antara lain ialah:

1. Berperan serta dalam menikmati hasil pembangunan.

2. Berperan serta dalam melaksanakan program pembangunan hal ini terjadi karena pihak luar masyarakat, sudah mengerjakan persiapan, perencanaan, dan menyediakan semua kebutuhan program.

3. Berperan serta dalam memelihara hasil program. Fungsi ini lebih sulit, apalagi kalau masyarakat tidak terlibat dalam pelaksanaan. Sulit, bukan saja karena tidak mempunyai keterampilan, tetapi yang lebih penting karena mereka merasa tidak memiliki program tersebut.

4. Berperan serta dalam menilai program. Fungsi ini kadang diambil masyarakat karena diminta oleh penyelenggara program dan masyarakat merasa program tidak sesuai dengan aspirasinya (Suprapto, 2007:11).

\section{Program Konversi Minyak Tanah Ke Gas LPG}

Anggito Abimanyu, Kepala Badan Fiskal (BKF) Departemen Keuangan mengungkapkan bahwa konversi minyak tanah merupakan upaya pemerintah mengerem peningkatan konsumsi bahan bakar minyak bersubsidi melalui penyediaan tabung gas dan sosialisasi. (http:www.pajak.go.id/konversiminyak-tanah $/ . . . h t m l$

Pendapat tersebut serupa dengan yang disampaikan oleh Fadhil Hasan, Ekonom Senior Indef ini mengungkapkan bahwa program konversi minyak tanah menjadi LPG merupakan upaya pemerintah untuk mengurangi beban subsidi bahan bakar minyak sehingga dapat mengurangi biaya yang harus dikeluarkan oleh pemerintah. (http:www.google.co.id/konversi/.../html).

\section{Metode Penelitian}

\section{A. Metode Penelitian}

Metode yang digunakan dalam penelitian ini adalah kualitatif yang bersifat deskriptif. Penelitian dilakukan pada bulan maret 2012 sampai april 2012.

Informan dipilih dengan tujuan mendeskripsikan suatu gejala sosial atau masalah sosial tertentu berdasarkan 
pertimbangan tertentu (purposive sampling). Informan dalam penelitian ini adalah berjumlah 20 orang. Sasaran dalam penelitian ini adalah mereka atau obyek yang dapat memberikan informasi sesuai dengan fokus penelitian ini.

\section{B. Fokus Penelitian}

1. Persepsi masyarakat mengenai konversi minyak tanah ke gas LPG:

a. Pengetahuan masyarakat tentang program konversi minyak tanah ke gas LPG.

b. Pemahaman masyarakat terhadap manfaat dari program konversi minyak tanah ke gas LPG tersebut.

2. Sikap masyarakat terhadap program konversi minyak tanah ke gas LPG:

a. Penilaian masyarakat terhadap konversi minyak tanah ke gas LPG.

b. Tanggapan masyarakat terhadap program konversi minyak tanah ke gas LPG bagi masyarakat.

3. Partisipasi masyarakat terhadap program konversi minyak tanah ke gas LPG:

a. Keikutsertaan masyarakat secara aktif dalam menjalankan konversi minyak tanah ke gas LPG.

b. Keterlibatan masyarakat dalam melaksanakan konversi minyak tanah ke gas LPG dengan penuh pemahaman dan evaluasi.

\section{Teknik Pemeriksaan Keabsahan Data}

Teknik pemeriksaan keabsahan data yaitu:

1. Ketekunan Pengamatan

Yaitu peneliti berusaha menemukan ciriciri dan unsur-unsur dalam situasi yang sangat relevan dengan persoalan atau isu yang sedang dicari, kemudian memusatkan diri pada hal-hal tersebut secara rinci.

2. Uraian Rinci

Yaitu cara melaporkan penelitian dengan teliti dan cermat yang dapat menggambarkan konteks tempat penelitian di selenggarakan, dengan tetap mengacu pada fokus penelitian.

\section{Teknik Analisis Data}

Teknik analisis data yang digunakan dalam penelitian ini ialah analisis model interaktif dari Miles dan Heuberman (2001),

1. Reduksi Data
Data yang diperoleh dari lapangan dituangkan dalam uraian atau laporan yang lengkap dan terinci.

2. Display Data

Langkah ini bertujuan memudahkan peneliti melihat gambaran secara keseluruhan atau bagian tertentu dari penelitian.

3. Verifikasi

Verifikasi data dalam penelitian kualitatif dilakukan secara terus menerus sepanjang proses penelitian berlangsung.

\section{Hasil Penelitian Dan Pembahasan}

\section{A. Rangkuman Hasil Penelitian}

Hasil penelitian dapat dirangkum, sebagai berikut :

1. Persepsi masyarakat terhadap konversi minyak tanah ke gas LPG di Kelurahan Tara-tara, cukup baik. Hal ini di tunjukkan oleh cukup banyaknya masyarakat yang mengetahui latar belakang, maksud, tujuan, sasaran dan manfaat dari adanya program ini.

2. Sikap masyarakat yakni menerima program konversi. Masyarakat menilai positif dan sangat mengharapkan konversi minyak tanah ke gas LPG.

3. Partisipasi masyarakat cukup tinggi. Masyarakat terlibat secara aktif dalam melaksanakan program konversi minyak tanah ke gas LPG dan melaksanakan konversi dengan penuh evaluasi dan pemahaman akan resiko yang bisa ditimbulkan dalam menggunakan gas LPG.

\section{B. Pembahasan Hasil Penelitian}

1. Persepsi masyarakat terhadap konversi minyak tanah ke gas LPG $3 \mathrm{~kg}$

Hasil penelitian menunjukkan bahwa persepsi masyarakat mengenai konversi minyak tanah ke gas LPG sebarannya dominan pada kategori cukup baik. Persepsi masyarakat yang cukup baik bermakna bahwa pengetahuan serta pemahaman masyarakat akan latar belakang, tujuan, sasaran dan manfaat dari adanya program konversi minyak tanah ke gas LPG cukup baik.

Hal ini sejalan dengan (Mahmud, 1990:55) yang mengungkapkan bahwa persepsi adalah suatu proses yang dimulai dari penglihatan dan pendengaran hingga terbentuk tanggapan yang terjadi pada diri individu sehingga individu sadar akan segala sesuatu 
dalam lingkungannya melalui indera-indera yang dimilikinya

2. Sikap masyarakat terhadap konversi minyak tanah ke gas LPG $3 \mathrm{~kg}$

Hasil penelitian menunjukkan bahwa sikap masyarakat terhadap konversi minyak tanah ke gas LPG sebarannya dominan pada kategori baik. Hal ini berarti bahwa masyarakat setuju dan menerima dengan baik adanya program konversi minyak tanah ke gas LPG karena manfaat yang dirasakan ketika menggunakan LPG sangat memuaskan. Masyarakat Kelurahan Tara-tara, Kecamatan Tomohon Barat Kota Tomohon menanggapi positif adanya konversi minyak tanah ke gas LPG.

LaPierre mendefinisikan sikap sebagai suatu pola perilaku, tendensi atau kesiapan antisipatif, predisposisi untuk menyesuaikan diri dalam situasi sosial atau secara sederhana, sikap adalah respon terhadap stimuli sosial yang telah terkondisikan. Definisi Petty \& Cacioppo secara lengkap mengatakan sikap adalah evaluasi umum yang dibuat manusia terhadap dirinya sendiri, orang lain, objek atau isu-isu (dalam Azwar, 2007).

3. Partisipasi masyarakat terhadap konversi minyak tanah ke gas LPG $3 \mathrm{~kg}$

Hasil penelitian menunjukkan bahwa partisipasi masyarakat terhadap konversi minyak tanah ke gas LPG sebarannya dominan pada kategori cukup tinggi. Hal ini berarti bahwa masyarakat terlibat secara aktif dalam melaksanakan program konversi minyak tanah ke gas LPG

Keterlibatan masyarakat dalam kegiatan seperti perencanaan dan pelaksanaan pembangunan disebut partisipasi dalam proses administratif (Bryant dan White, 1989 : 270).

\section{Kesimpulan Dan Saran}

\section{A. Kesimpulan}

Kesimpulan penelitian sebagai berikut :

1. Persepsi masyarakat terhadap konversi minyak tanah ke gas LPG di Kelurahan Tara-tara, Kec. Tomohon Barat, Kota Tomohon belum sepenuhnya baik. Sebagian masyarakat belum mengetahui latar belakang, tujuan dan sasaran dari program konversi minyak tanah dengan baik. Hal ini tercermin dari adanya masyarakat yang tidak mengetahui sama sekali akan latar belakang dan tujuan kenapa program konversi minyak tanah ke gas ini di cetuskan oleh pemerintah. Bagi sebagian masyarakat, yang terpenting adalah manfaat yang didapatkan ketika menggunakan LPG sangat dirasakan.

2. Sikap masyarakat terhadap konversi minyak tanah ke gas LPG di Kelurahan Tara-tara, Kecamatan Tomohon Barat, Kota Tomohon adalah menerima dengan baik program konversi minyak tanah ke gas LPG ini. Ada beberapa hal yang dikeluhkan masyarakat yaitu banyak tabung yang sudah berkarat, harga yang selalu berubah, banyak tabung yang macet, stok yang kurang lancar dan isi tabung sering tidak sesuai dengan berat yang seharusnya.

3. Partisipasi masyarakat terhadap konversi minyak tanah ke gas LPG di Kelurahan Tara-tara, Kecamatan Tomohon Barat, Kota Tomohon cukup tinggi. Masyarakat antusias dalam melaksanakan konversi. Tingginya partisipasi masyarakat terhadap program konversi minyak tanah ke gas LPG hal ini mengimplikasikan bahwa masyarakat Kelurahan Tara-tara, Kecamatan Tomohon Barat, Kota Tomohon berada pada kategori masyarakat transisi dari tradisional ke masyarakat modern. Masyarakat paham akan resiko dari konversi ini dan menjalankan konversi minyak tanah ke gas LPG ini dengan penuh kewaspadaan dan kehatihatian.

\section{B. Saran}

Berdasarkan kesimpulan tersebut maka dapat disarankan beberapa hal, yaitu sebagai berikut :

1. Perlu dilakukan sosialisasi secara terus menerus dan memberikan jaminan bahwa menggunakan LPG aman sehingga masyarakat tidak perlu takut untuk menggunakan gas LPG.

2. Pemerintah dan Pertamina harus segera menambah jumlah pangkalan yang ada, segera menetapkan harga eceran tertinggi di pasaran dan menarik semua tabung yang berkarat. Memberikan sanksi kepada pihak yang melakuan kecurangan yang dengan sengaja menjual tabung yang isinya tidak sesuai dengan berat yang seharusnya.

3. Pemerintah perlu tetap menyediakan minyak tanah, karena ada masyarakat yang masih menggunakan minyak tanah. 


\section{DAFTAR PUSTAKA}

Abdul Wahab, S., 2002. Analisis Kebijakan Dari Formulasi Ke Implementasi Kebijakan Negara, Bumi Aksara, Jakarta.

Alun, Tawang. 1992. Analisa Ekonomi Utang Luar Negeri, LP3ES, Jakarta.

Arif, Sritua, 1998. Teori dan Kebijaksanaan Pembangunan, CIDES, Jakarta.

Dorodjatun Kuncoro-Jakti, 1994. Kemiskinan Di Indonesia. Jakarta, Jayasan Obor, Indonesia.

Dwiyanto, A. 2002. Pemerintah Yang Efisien, Tanggap dan Akuntabel: Kontrol Atau Etika, Jurnal Kebijakan dan Administrasi Publik, Jakarta.

George Ritzer, Douglas J. Goodman, 2004. Teori Sosiologi Modern. Prenada. Media Indonesia.

Mardiasmo. 2008. Otonomi Manajemen Keuangan Daerah, Andi, Yogyakarta.

Stephen, Robbins.2007. Manajemen. PT. Indeks, Jakarta.

Sugiyono, 2009. Metode Penelitian Kualitatif, Kuantitatif dan R\&D. Alfabeta, Bandung.

Tambunan, T.H. 2003. Perekonomian Indonesia. Ghalia Indonesia, Jakarta.

http://www. Pajak.go.id/ konversi-minyak-tanah/.../htm

http://www. Pertamina.com/konversi/taq.php

http://www.esdm.go.id/index.php?

http://www.elibrary.mb.ipb.ac.id/adl.php?mod-browse\&op-read.. 